\title{
The Effects of Remittances on Economic Growth in West Africa
}

\author{
Mavis Adjei ${ }^{*}$, Yu Bo ${ }^{1}$, Emmanuel Nketiah², Gibbson Adu-Gyamfi², Bright Obuobi ${ }^{3}$ \\ ${ }^{1}$ School of Business, Nanjing University of Information Science \& Technology, Pukou District, Nanjing, China \\ ${ }^{2}$ School of Economics and Management, Nanjing University of Science and Technology, Xuanwu District, Nanjing, China \\ ${ }^{3}$ College of Economics and Management, Agricultural and Forestry Economics and Management, Nanjing Forestry University, \\ Nanjing, China \\ Email: ^oseikai@hotmail.com, ^yubo@nuist.edu.cn, nketiah888@hotmail.com,ggimagin@gmail.com, obuobibright@gmail.com
}

How to cite this paper: Adjei, M., Bo, Y., Nketiah, E., Adu-Gyamfi, G., \& Obuobi, B. (2020). The Effects of Remittances on Economic Growth in West Africa. Journal of Human Resource and Sustainability Studies, 8, 312-329.

https://doi.org/10.4236/jhrss.2020.83018

Received: August 13, 2020

Accepted: September 15, 2020

Published: September 18, 2020

Copyright $\odot 2020$ by author(s) and Scientific Research Publishing Inc. This work is licensed under the Creative Commons Attribution International License (CC BY 4.0).

http://creativecommons.org/licenses/by/4.0/

\begin{abstract}
This paper is an attempt to investigate the cointegration and Granger causal relationship between remittances and economic growth in West Africa with special reference to Burkina-Faso, Ghana, Guinea, Guinea-Bissau, Mali, Nigeria, and Togo. Different from limited existing countries studies in west Africa, an advanced panel econometric methodology such as dynamic Panel data techniques, considers the question of remittances on economic growth in West Africa. Our results suggest that remittances on economic growth in West Africa exert a positive and significant impact. Furthermore, a positive relationship between remittance, real effective exchange rate, trade openness, investment on economic growth was detected. Thereby it is important to examine the causal effects of both remittances and economic growth in West Africa, which conclude the existence of a short-term relationship between remittance and economic growth in West Africa. The above findings and conclusions informed the following recommendations: There is a need for carefulness in the management of funds sent home by migrants. Such monies are expected to be guided into productive ventures and not for wastefulness. To earn the full benefits of improved migrant's remittances, West Africa must create an investment climate that is appealing to Africans in the diaspora. Lastly, there is equally the need for West Africa economies to rely more on domestic investment rather than on foreign capital inflows for their economic growth.
\end{abstract}

\section{Keywords}

Remittance, Economic Growth, Exchange Rate, Trade Openness 


\section{Introduction}

Scholastically, remittances can stimulate economic growth through a medium such as promoting financial market activities, serving as a source of funding for business activities, shock insurance, household expenses financing, capital formation for household, means of bridging savings and external funding gaps. Based on this, it has been empirically established in a segment of the literature that, remittances lead to economic growth (Ramirez, 2013; Lartey, 2011; Atiga et al., 2014; Adenutsi, 2011).

In certain scenarios and circumstances, remittances can, however, diminish economic growth. This may arise if receivers intend or use the remittances earned to reduce their supply of labor to the economy. When this happens, the receivers who are considered part of the active workforce will become completely reliant on the migrant solely for survival. This was the reason why (Molina et al., 2007) wrote that, where remittance inflows contribute to so much appreciation of the local currency, it can also affect the country's economy as it discourages exports, thus reducing the recipient's entrepreneurial competitiveness.

This huge volume of the workforce should be occupied with work to guarantee their interest in the economic development of the country too to improve their way of life. The migration of a huge work power brings about higher remittance inflows in the nation. It very well may be referenced that the inflow of remittance is expanding throughout the year in West Africa which assumes a significant job in the improvement of the migrant families and the nations too. Remittance has become a fundamental part of financial headway for growing West African nations. The motivation behind this examination is to analyze experimentally whether settlements lead to economic development in West Africa in spite of the two wellsprings of writing. Consequently, it will break down whether settlements sway financial development or not. Even though there has been a great deal of work with regards to remittances and economic growth, most investigations have focused on whether settlements add to economic development or not. In contrast, other studies have typically used panel data to study developing countries, making these researches very difficult to answer specific issues in countries as in the study of (Mcgillivray et al. 2014, Jones \& Driffield, 2013). Concerning this study, Adenutsi (2011) explored the causal link between remittances and economic growth but emphasized the use of financial development as a medium for Ghana's economic development. In Selvanathan et al. (2012) study, the causality relationship among Bangladesh, Sri Lanka, and the Indian economy was investigated. Although the used methodology is very similar, economically and geographically the countries involved in the study differ. Therefore, the various outcomes can be expected from the research. In addition to filling the literature gap, the study will provide lawmakers with guidance on labor mobility and the processes involved in obtaining remittances.

The remittances flow in West Africa has grown not only in size but also in importance regarding the share of gross domestic product (GDP). Remittances represent the second-largest source of foreign currency earnings after exports, which have contributed above 10 percent of GDP (Chowdhury 2011). A study of 
Hasan (2006) shows that remittance has a significant macroeconomic impact at the household level. He added that the more impact or benefit remittance income can have is to alleviate poverty. Jongwanich (2007) discovered that remittances have a significant but marginal influence on economic growth in Asia and Pacific countries. Therefore, it signifies important to determine the effect of remittance on the economy in West Africa. Thus, this study attempts to investigate the cointegration and Granger causal relationship between remittances and economic growth in West Africa with special reference to Burkina-Faso, Ghana, Guinea, Guinea-Bissau, Mali, Nigeria, and Togo. The study also examines the effect of Long run cointegration test results of remittance on economic growth which the study would first test the data for stationarity. The stationarity characteristics of the data set by using Levin-lin-Chu, Im-Pesaran-Shin, and Maddala $\& \mathrm{Wu}$ respectively. If the variables are stationary at the first difference, which appears to be the most presumable cause for panel data, the method of cointegration can be applied to study the relationship. If there is cointegration between the variables, the short-run relationship can be established through the vector error correction model (VECM). Besides, in the cause of the absence of cointegration, the study would progress with Granger causality in the vector autoregressive (VAR) framework. The structure of the paper is as follows. In Section 2 by a short review of the literature on the remittance and economic growth in West Africa. In Section 3 the remittance on the seven West African countries. In section 4 the data and methodology used are discussed and results and analysis, while section 5 presented concluding remarks and recommendation.

\section{Literature Review}

Recently international migrants' remittances from emerging economies have drawn the attention of scholars, authorities, and governments. This growing curiosity and analysis into the ever-increasing flows of remittances to developing countries led to experts having to express divergent views on their consequences for economic growth and development. Remittances are believed to provide a stimulus for improved economic growth and development because they increase households' purchasing power. They provide additional working capital for recipient household private enterprises that are frequently resident in low-income economies.

The influence of remittances on growth was categorized into three ways (Barajas et al., 2009). First, by boosting the rate of capital accumulation, remittances not only raise the rate of human capital and physical but also drop the cost of capital in the recipient country. The second effect is connected to the resultant change in labor force growth. Remittances may harm the participation of labor force as the remittance income is substituted for labor income. Third, remittances influence the efficiency of investment by affective TFP growth. The greater part of the country level investigations depends on the household's unit information as bits of knowledge into how remittances influence households at the smaller scale level. Existing macro empirical works on remittances mainly focus on growth, poverty, inequality and output growth volatility. Most of the analyses 
on remittances use households to examine the outcomes of remittances. Three key strands of economic works exist on the part of remittances. Current empirical findings have generally argued that remittances have a positive effect on economic growth in developing countries. Gaiha et al. (2014) most lately investigated the empirical link amongst economic growth, remittances, and poverty discovered that remittances limb economic growth and reduce poverty in the region. Selvanathan et al. (2012) study seemed to be no causal link between growth in remittances and economic growth; at the same time as in Sri Lanka, a bi-directional causality was established; namely, economic growth influences growth in remittances and vice-versa. Lartey's (2012) results indicated a positive relationship between remittances and growth, aside from a positive interaction effect between remittances and financial depth on growth and also discovered verge ethics for two key indicators of financial development, above which the remittances show strong positive relationship on growth.

Kanu and Ozurumba (2013) in their investigation of migrant's remittances and economic growth in sub-Saharan Africa: evidence from Nigeria, Ghana, and South Africa indicated that migrants' remittances are found to have a positive impact on the economic growth of Nigeria, Ghana, and South Africa. It was revealed that the greatest impact was on South Africa, followed by Ghana and Nigeria. Marwan et al. (2013) used a time-series study from Sudan by Johansen Cointegration technique to examine the link amongst export, aid, remittances, and growth and located that there is a long-run positive relationship amongst growth, export, and remittance. Salahuddin (2013) used the panel OLS method to guess the growth effects of remittances in Bangladesh, India, Pakistan, and the Philippines and found a positive relationship. Rao and Hasan (2011) related the panel cointegration technique in an analysis of an unbalanced panel of 40 countries and investigated the direct growth effects of remittances and the channels within which remittances affect growth. It was established that though there have been short to average term transitory growth effects, there are no long-run growth outcomes of remittances. The results are reliable with those of Giuliano and Ruiz-Arranz (2009).

Naiditch and Vrancianu (2010) in an analysis of 25 countries from Eastern Europe and Central Asia displayed that a rise in migrant income hints to a rise in invested but not consumed remittances. Bugamelli and Paterno (2009) showed that worker's remittances help reduce the probability of current account reversals. They advocate that efforts to decrease the cost and the risk of assigning remittances across countries should be on our political memo both at national and international levels. Pradhan et al. (2008) confirmed the positive growth effect of remittance in a panel of 39 developing countries. Remittances have a positive influence on the rates of savings and public expenditure, not only on level and growth rates of GDP per capita (Ziesemer, 2010).

Majumder and Donghui (2016) have examined the impact of remittances, trade and money supply on the economic growth of Bangladesh, by employing the Bounds testing approach. The Bounds test recommended that the remittances have only a long-run positive relationship with the economic growth of 
Bangladesh. Mcgillivray et al. (2014) also examined the impact of remittances on economic growth in Small Island Developing States (SIDS). It was recommended that while, on average, there is at greatest no association between remittances and growth in developing countries, there is a positive association among these variables in SIDS. This discovery holds for SIDS in sub-Saharan Africa and the Pacific but not for those in Latin America and the Caribbean.

Even though most of the studies advocate remittances' positive effect in developing countries, critics argues that the growth effects of remittances are either negative or at best zero. Guha's (2013) findings highlight the fact that remittances may lead to real exchange rate appreciation leading to sectoral production reallocation by applying the Dutch Disease theory to explain the results of remittances on the economy and presented a micro-macro framework to establish channels of transmission of remittances through the economy. Nketiah et al. 2019 investigated the impact of remittance on the real exchange rate in Ghana, by employing time series data over 47 periods and found that remittance has no significant impact on the real exchange rate in Ghana. Other corresponding variables lead to the real exchange rate positively. He suggests that a change in the real exchange rate is generally related to movement in economic fundamentals. It was revealed by Oluyemi et al. (2015) that remittances have expressively supported savings and investment in Nigeria involving community-based development projects and charity support activities. Barajas et al. (2009) and Chami et al. (2003) establish a negative relationship between remittances and economic growth. Catrinescu et al. (2009) located neither positive nor negative relationship between remittances and growth. Also, the findings of Selvanathan et al. (2012) showed that growth in remittances does not relate to economic growth in Bangladesh. The above argument on remittances and economic growth indicate that the effects of remittances on economic growth are mixed. Though sufficiently of works on remittance-growth relationship survive now, the capacity of country-level studies is still relatively limited. Some studies also support the positive effect of remittances (Salahuddin \& Gow, 2015; Javid et al. 2012; Ang, 2007). It was presented that output alone determined long-run movements in remittances in a positive direction in the last 35 years in Bangladesh (Paul, et al. 2011).

There have been not very many examinations that researched the impact of remittances on poverty. Adams et al. (2013) result supports the strong role of remittances in reducing poverty and enhancing investment in health, education, and housing by using time series cointegration technique for Ghana to research the relationship between remittances and poverty reduction and investment in education, housing, and health. Ziesemer (2012) discoveries that the total consequence of remittances on levels and growth rates of GDP per capita, investment and literacy are positive. Vargas et al. (2009) findings signify that remittances limb economic growth and reduce poverty. Gupta et al., (2009) determined that remittances have a direct poverty-mitigating effect and a positive impact on financial development. Khawaja and Nath (2010) suggested that at the household level, remittances reduce poverty while they have a significant effect 
on macro variables in the Bangladesh economy. Remittances donate towards financial extending also Gupta et al. (2009) showed that remittances have a direct poverty mitigating effect and it promoted economic development by using random effect and fixed-effect models for a panel of Sub-Saharan African countries.

Remittances also aid reduce consumption instability in developing countries. Combes and Ebeke (2011) indicated that remittances significantly reduce consumption instability and its effect is even stronger for financially less developed countries. Remittances also raise the capacity to survive with natural disasters and macroeconomic shocks. Notwithstanding the rising importance of remittances in total international capital flows, the relationship between economic growth and remittances has not been satisfactorily considered (Fayissa \& Nsiah, 2010). In persistence to their place, the studied the aggregate impact of remittances on economic growth within the conventional neoclassical growth framework using panel data spanning between the years 2004 to 2018 for 7 West African countries. It was found that remittances positively impact economic growth by offering an alternative way to finance investment and assisting to overcome liquidity.

\section{The Remittance Trend in West Africa}

Remittances play a significant role in West Africa economy, as is the case in many developing countries. According to the World Bank, West Africa countries are among the top remittance countries in the world. Figure 1 shows the remittance trend in Burkina-Faso, Ghana, Guinea, Guinea-Bissau, Mali, Nigeria and Togo. According to the figure below Nigeria is the country with the highest level of remittance in terms of these seven countries in West Africa. From 2004 to 2018 Nigeria has been a persistent increase in remittance level in their country. Ghana is the second-highest level of remittance within these seven (7) West Africa countries but Ghana has also been a persistent increase in remittance till 2015 which rises and declines next year but has a constant increase from then. Mali is the third-highest follow by Burkina Faso, Guinea and Guinea-Bissau in terms of increasing level of remittance. Togo is the country with a low level of remittance according to these seven countries in West Africa.

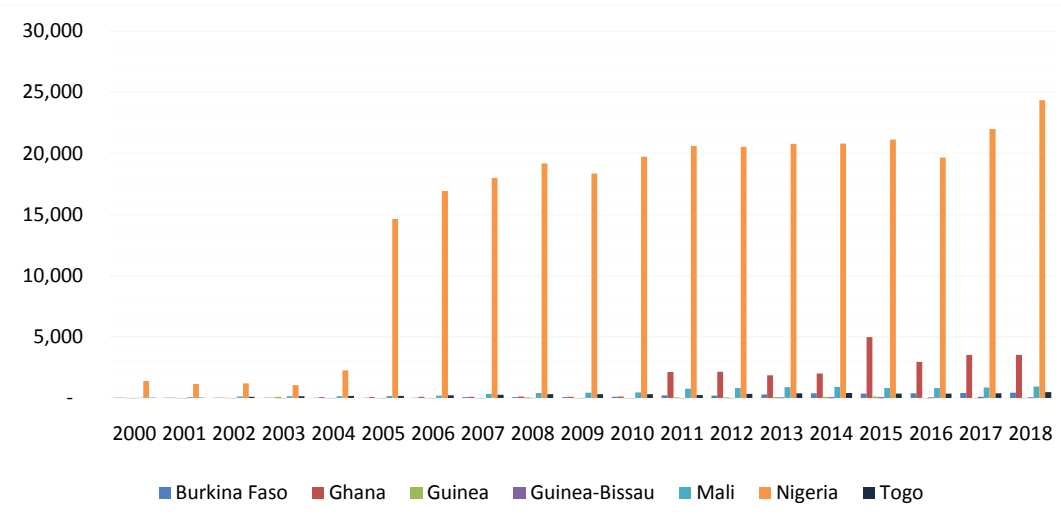

Figure 1. The remittance trend in Burkina-Faso, Ghana, Guinea, Guinea-Bissau, Mali, Nigeria, and Togo. 


\section{Data and Methodology}

Here the presentation of the model to be estimated as well as the different methods of estimation most suitable for our study will be shown in the first part. The different application of stationarity and cointegration tests while highlighting the importance of these tests for the empirical analysis framework for dynamic panel models will be presented in the second part. And we will finalize by the interpretation of the estimated model results.

\subsection{Data Description}

Our empirical study uses panel data for the West Africa countries during the period 2003-2018 by using a dynamic panel data analysis. The choice of the starting period is constrained by the availability of data. The data for this study will be acquired from World Bank website. The variables consist of GDP, Real effective exchange rate, remittance, investment, trade openness and domestic savings. Table 1 presents description of the variables in the study. Figure 2 shows the study model.

Model: This thesis model will consist of following.

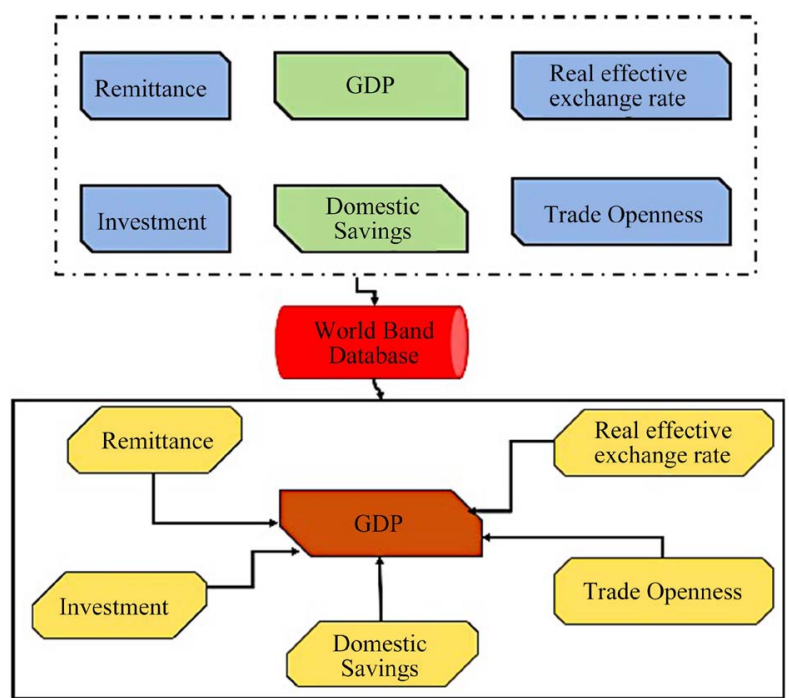

Figure 2. Conceptual diagram for the proposed study.

Table 1. Description of the variables.

\begin{tabular}{ll}
\hline Variable & Description \\
\hline GDP & $\begin{array}{l}\text { Gross value added by all resident producers in the } \\
\text { economy }\end{array}$ \\
Remittance (REMITT) & Migrant remittance inflows \\
Investments & Gross fixed capital formation \\
Trade Openness (TOPEN) & Export plus import \\
Real effective exchange rate (REER) & Local currency unit relative to the US dollar \\
Domestic Savings & Gross domestic savings
\end{tabular}




\subsection{Methodology}

Following the work of Kahouli and Maktouf (2014) and Moradbeigi and Law, (2017), we employ the dependent variable in this model, GDP represents economic growth. The independent variables include REER is measured as Real effective exchange rate, Migrant remittance inflows as a proxy of Remittance and investment is measured as Gross fixed capital formation. The variable trade openness is proxied by export plus import and domestic savings are Gross domestic savings. Investment is a measure of Gross fixed capital formation. The functional form of the model is as follows:

$$
\begin{aligned}
\operatorname{GDP}_{i t}= & D_{i t} \text { REMITT }_{i t}^{a 1} \text { REER }_{i t}^{a 2} \text { INVESTMENT }_{i t}^{a 3} \text { TOPEN }_{i t}^{a 4} \\
& \times \text { DOMESTICSAVINGS Sit }_{i t-1}^{a 5} Y^{a 6}
\end{aligned}
$$

It should be noted that we have converted all the series into logarithms because the simple linear specification does not seem to provide consistent results. So, this transformation facilitates the interpretation of the estimated coefficients which are read as elasticities. Also, it can control the heteroscedasticity problem. Indeed, the logarithmic transformation makes it possible to solve or reduce the differences between the variables linked to the differences in their units of measure.

The logarithmic transformation of Equation (1) is given by:

$$
\begin{aligned}
\ln \mathrm{GDP}_{i t}= & \beta_{0}+\beta_{1} \ln \mathrm{REMITT}_{i t}+\beta_{2} \ln _{\text {REER }}+\beta_{3} \ln \text { INVESTMENT }_{i t} \\
& +\beta_{4} \ln \text { TOPEN }_{i t}+\beta_{5} \ln \text { DOMESTICSAVINGS }_{i t}+\beta_{6} \ln Y_{i t-1} \varepsilon_{i t}
\end{aligned}
$$

The subscript $i$ denotes the country $(i=1, \cdots, 15)$ and $t$ indicates the time period $(t=2004, \cdots, 2018)$. $\ln \mathrm{GDP}_{i t}$ refers natural $\log$ of GDP, $\ln \mathrm{REMITT}_{i t}$ reveals Migrant remittance inflows as a proxy of Remittance, $\ln \mathrm{REER}_{i t}$ shows natural log of Real effective exchange rate indices, ln INVESTMENT ${ }_{i t}$ implies a natural log of Investment is a measure of Gross fixed capital formation and trade openness is proxied by $\left(\ln\right.$ TOPEN $\left._{i t}\right)$, $\ln$ DOMESTICSAVINGS $_{i t}$ shows natural $\log$ of domestic savings is Gross domestic savings, while $\varepsilon_{i t}$ is error term. a1, a2, a3, a4, a5 and $a 6$ are the output elasticities respectively with respect to remittance, Real effective exchange rate, Investment, GDP, trade openness and domestic savings.

In this study, a dynamic Panel data analysis will be used to test the three-way relationship. The first step of our analysis is to make sure of the stationarity of the series or of the order of integration of each of them. Therefore, the study of the stationarity of each series is based on two types of tests. First-generation tests Kahouli and Maktouf (2014), Madalla \& Wu (1999) and second-generation tests Pesaran (2003). Both of tests is based on two hypotheses the null hypothesis of the presence of a unit root (non-stationary) against the alternative hypothesis of absence of unit root (stationary) the results of the test are given in Table 2 bellow for a sample of 7 countries (Burkina-Faso, Ghana, Guinea, Guinea-Bissau, Mali, Nigeria, and Togo) of West Africa. 
Table 2. Unit root tests results.

\begin{tabular}{|c|c|c|c|c|c|c|c|c|}
\hline \multirow{3}{*}{ Variable } & \multirow{2}{*}{\multicolumn{2}{|c|}{ LLC }} & \multirow{2}{*}{\multicolumn{2}{|c|}{ IPS }} & \multicolumn{4}{|c|}{ MW } \\
\hline & & & & & \multicolumn{2}{|c|}{ ADF-Fisher } & \multicolumn{2}{|c|}{ PP-Fisher } \\
\hline & Level & $\begin{array}{c}\text { First. } \\
\text { Deference }\end{array}$ & Level & $\begin{array}{c}\text { First. } \\
\text { Deference }\end{array}$ & Level & $\begin{array}{c}\text { First. } \\
\text { Deference }\end{array}$ & Level & $\begin{array}{c}\text { First. } \\
\text { Deference }\end{array}$ \\
\hline REMITT & $\begin{array}{c}0.2357 \\
(0.5932)\end{array}$ & $\begin{array}{c}-1.9848 \\
(0.0236)^{\star *}\end{array}$ & $\begin{array}{c}1.3074 \\
(0.9045)\end{array}$ & $\begin{array}{c}-3.6394 \\
(0.0001)^{\star * *}\end{array}$ & $\begin{array}{l}5.85218 \\
(0.9701)\end{array}$ & $\begin{array}{c}37.0018 \\
(0.0002)^{\star * *}\end{array}$ & $\begin{array}{c}27.9698 \\
(0.0144)^{\star *}\end{array}$ & $\begin{array}{c}106.135 \\
(0.0000)^{* * *}\end{array}$ \\
\hline GDP & $\begin{array}{c}-3.6870 \\
(0.0001)^{\star * *}\end{array}$ & $\begin{array}{c}-5.6448 \\
(0.0000)^{\star * *}\end{array}$ & $\begin{array}{c}-2.2479 \\
(0.0123)^{\star *}\end{array}$ & $\begin{array}{c}-5.1670 \\
(0.0000)^{* * *}\end{array}$ & $\begin{array}{c}25.6949 \\
(0.0283)^{\star \star}\end{array}$ & $\begin{array}{c}50.5181 \\
(0.0000)^{\star * *}\end{array}$ & $\begin{array}{c}33.0266 \\
(0.0029)^{\star *}\end{array}$ & $\begin{array}{c}113.070 \\
(0.0000)^{\star \star \star}\end{array}$ \\
\hline REER & $\begin{array}{c}-3.0349 \\
(0.0012)^{\star *}\end{array}$ & $\begin{array}{c}-7.2449 \\
(0.0000)^{* * *}\end{array}$ & $\begin{array}{c}-1.8990 \\
(0.0288)^{\star *}\end{array}$ & $\begin{array}{c}-5.1544 \\
(0.0000)^{\star * \star}\end{array}$ & $\begin{array}{c}22.8115 \\
(0.0634)^{\star}\end{array}$ & $\begin{array}{c}50.3274 \\
(0.0000)^{\star * *}\end{array}$ & $\begin{array}{c}32.9657 \\
(0.0029)^{\star *}\end{array}$ & $\begin{array}{c}94.0523 \\
(0.0000)^{\star * *}\end{array}$ \\
\hline INVESTMENT & $\begin{array}{c}-2.4178 \\
(0.0078)^{\star *}\end{array}$ & $\begin{array}{c}-4.3792 \\
(0.0000)^{* * \star}\end{array}$ & $\begin{array}{l}-0.9366 \\
(0.1745)\end{array}$ & $\begin{array}{c}-3.9461 \\
(0.0000)^{* * *}\end{array}$ & $\begin{array}{l}16.9993 \\
(0.2562)\end{array}$ & $\begin{array}{c}39.7626 \\
(0.0003)^{* * *}\end{array}$ & $\begin{array}{l}20.1832 \\
(0.1245)\end{array}$ & $\begin{array}{c}73.3273 \\
(0.0000)^{* * *}\end{array}$ \\
\hline DOMESTICSAVINGS & $\begin{array}{c}-1.6912 \\
(0.0454)^{\star *}\end{array}$ & $\begin{array}{c}-5.2353 \\
(0.0000)^{* * *}\end{array}$ & $\begin{array}{l}-0.4201 \\
(0.3372)\end{array}$ & $\begin{array}{c}-4.3362 \\
(0.0000)^{\star * *}\end{array}$ & $\begin{array}{l}16.7233 \\
(0.2707)\end{array}$ & $\begin{array}{c}43.7270 \\
(0.0001)^{\star * *}\end{array}$ & $\begin{array}{l}16.9014 \\
(0.2615)\end{array}$ & $\begin{array}{c}103.296 \\
(0.0000)^{\star * *}\end{array}$ \\
\hline TOPEN & $\begin{array}{c}-1.9489 \\
(0.0257)^{\star *}\end{array}$ & $\begin{array}{c}-4.3641 \\
(0.0000)^{* * *}\end{array}$ & $\begin{array}{l}-0.3731 \\
(0.3545)\end{array}$ & $\begin{array}{c}-3.2728 \\
(0.0005)^{* * *}\end{array}$ & $\begin{array}{l}18.6611 \\
(0.1783)\end{array}$ & $\begin{array}{c}34.088 \\
(0.0020)^{* *}\end{array}$ & $\begin{array}{c}24.4299 \\
(0.0406)^{\star *}\end{array}$ & $\begin{array}{c}72.2726 \\
(0.0000)^{* * *}\end{array}$ \\
\hline
\end{tabular}

${ }^{* * *} ;{ }^{* *}$ and ${ }^{*}$ show stationarity at $1 \%, 5 \%$ and $10 \%$ level respectively.

After getting assumed about order of integration of the different series, we apply the Perdoni cointegration test, which allows studying the existence of a long-term relationship between remittance and economic growth for West Africa. Then, in order to complete the cointegration test, we proceed to estimate by the method "FMOLS" Full Modified Ordinary Least Square.

\subsection{Results of Econometric Modeling}

In this section, we will present the results of the estimates made for 7 West Africa countries. The first step is to present the unit root test to determine the stationarity of the variables. The second step is to implement the Perdoni cointegration test to check for cointegration between variables. Once relationships are determined, we can estimate a Vector error correction model.

\subsection{Results of Unit Root Tests}

The table below gives the results of the unit root tests according to Levin, Lin, and Chu (2002), Im, Pesaran, and Shin (2003) and Maddala \& Wu (1999) respectively.

Since Levin's test, Moradbeigi and Law (2017), proposes the dependence between individuals under the alternative hypothesis; the IPS test intervenes to lift this hypothesis and proposes independence between individuals under the alternative hypothesis. The fact that we have data missing the test McKinnon (1973) and especially the PP-Fisher test is more adequate Typically, the results in Table 2 indicate that most of variables used are integrated of I (1). On the one hand, the PP-Fisher test, do not allow to reject the null hypothesis of the presence of a unit root. The investment and domestic savings are not stationary in 
level. On the other hand, the null hypothesis of the presence of a unit root is rejected, unanimously for all series in the first difference.

\subsection{Results of Cointegration Tests of Perdoni (1999)}

The Jalil and Feridun (2011) test was employed to determine the presence of cointegration among variables. The results showed in Table 3 reveal that the probability of the majority of tests is less than $1 \%$, which allows us to reject the null hypothesis of the absence of cointegration and to accept the alternative hypothesis of the presence of cointegration. So, the variables are remittance and GDP. And subsequently, the hypothesis of a long-term relationship between these variables was confirmed.

\subsection{Results of VECM Model}

VECM Granger causality approach makes it possible to determine the meaning as well as the intensity of short-term relationships and to indicate the rate of long-term adjustment.

We start with the long-term causality study. Indeed, we are talking about a long-term causality between economic growth and the remittance and GDP variables when $\mathrm{c}(1)$ has a negative coefficient and a significant $\mathrm{p}$-value, that is to say, less than 0.05 , which is our case. Indeed, the result of our estimation of the VECM model of the long-term relationship presents a negative coefficient $(-0.569351)$ and significant $\mathrm{p}$-value (prob $=0.0000<0.05)$. This allows us to conclude that both remittance and GDP which are explanatory variables in this specification causes economic growth, by the way, so the process converges in the long run; Table 4.

For the short-term causality test, the procedure is based on Wald's test and subsequently the interpretation of the probability associated with the chi-square test. Indeed, when the probability of chi-square testing is greater than 0.05 , we notice that there isn't a short-term causality between the explanatory variable end question and the dependent variable Table 5.

Table 3. Perdoni cointegration test result (1999).

\begin{tabular}{ccc}
\hline & Statistic & Probability \\
\hline Panel v-Statistic & 0.5182 & 0.3022 \\
Panel rho-Statistic & -1.7670 & $0.0386^{* *}$ \\
Panel PP-Statistic & -2.8256 & $0.0024^{\star * *}$ \\
Panel ADF-Statistic & -1.8409 & $0.0328^{* *}$ \\
Group rho-Statistic & -0.7433 & 0.2286 \\
Group PP-Statistic & -2.9372 & $0.0017^{* * *}$ \\
Group ADF-Statistic & -1.9484 & $0.0257^{* *}$ \\
\hline
\end{tabular}

Ho: No cointegration, Ha: All panels are cointegrated, ${ }^{* * ;} ;{ }^{* *}$ and ${ }^{*}$, variables are cointegrated to $1 \% ; 5 \%$; $10 \%$. 
Table 4. Long run cointegration test results.

\begin{tabular}{ccccc}
\hline & Coefficient & St. Error & t-Statistic & Prob \\
\hline C $(1)$ & -0.5694 & 0.1143 & -4.9809 & $0.0000^{* * *}$ \\
\hline
\end{tabular}

${ }^{* * *} ;{ }^{* *}$ and ${ }^{*}$ show significant at $1 \%, 5 \%$ and $10 \%$ level respectively.

Table 5. Wald test result on the short-term causality between remittance and GDP.

\begin{tabular}{cccc}
\hline Test Statistic & Value & df & Probability \\
\hline F-statistic & 17.2458 & $(2,87)$ & 0.0000 \\
Chi-square & 34.4915 & 2 & $0.0000^{* * *}$ \\
& Null Hypothesis: $\mathrm{c}(1)=\mathrm{c}(2)=0$ & & \\
& Null Hypothesis Summary: & & Std. Err \\
Normalized Restriction (=0) & Value & 0.1143 \\
& & -0.5694 & 0.1078 \\
& C $(1)$ & 0.0211 & \\
\end{tabular}

The Wald's test results showed a probability of chi square (0.0000) is less than 0.05 , which allows us to accept the alternative hypothesis that stimulates the existence of a short-term relationship. This allows us to conclude the existence of a short-term relationship between remittance and GDP.

\subsection{GMM Test Results}

Estimation Equation

$$
\begin{aligned}
\text { LGDP }= & C(1)+C(2) * \text { LREMITT }+C(3) * \text { LREER } \\
& +C(4) * \text { LDOMESTICSAVINGS } \\
& +C(5) * \text { LINVESTMENT }+C(6) * \text { LTOPEN }+\varepsilon_{i t}
\end{aligned}
$$

Substituted Coefficients:

$$
\begin{aligned}
\text { LGDP }= & 8.45367+0.636562 * \text { LREMITT }+2.344571 * \text { LREER } \\
& -0.912028 * \text { LDOMESTICSAVINGS } \\
& +1.321245 * \text { LINVESTMENT }-0.07225 * \text { LTOPEN }+\varepsilon_{i t}
\end{aligned}
$$

\begin{tabular}{ccccc}
\hline Variable & Coefficient & St. Error & t-Statistic & Probability \\
\hline C & 8.4537 & 3.4629 & 2.4412 & 0.0168 \\
LREMITT & 0.6366 & 0.0460 & 13.8468 & $0.0000^{* * *}$ \\
LREER & 2.3446 & 0.6863 & 3.4161 & $0.0010^{* * *}$ \\
LTOPEN & -0.9120 & 0.2104 & -4.3353 & $0.0000^{* * *}$ \\
LINVESTMENT & 1.3213 & 0.2826 & 4.6758 & $0.0000^{* * *}$ \\
LDOMESTIC_SAVINGS & -0.0722 & 0.1072 & -0.6742 & 0.5021 \\
R-squared & 0.8679 & Mean dependent var & 23.4247 \\
Adjusted R-squared & 0.8598 & S.D. dependent var & 1.7061 \\
S.E. of regression & 0.6389 & Sum squared resid & 33.0584 \\
Durbin-Watson stat & 0.2624 & & J-statistic & 81.0000 \\
Instrument rank & 7 & PROB (J-statistic) & 0.0000
\end{tabular}

${ }^{* * *} ;{ }^{* *}$ and ${ }^{*}$ show stationarity at $1 \%, 5 \%$ and $10 \%$ level respectively. 
The results in table show a robust Adjusted R-square of about 0.867943 indicating that about $86.79 \%$ change in dependent variable (GDP) is jointly explained by the explanatory variables (REMITT, REER, INVESTMENT, DOMESTICSAVINGS, TOPEN), while only $0.05 \%$ present change in the dependent variable, that is, economic growth fluctuation can be said to be explained by factors outside the model. The result indicates also, that TOPEN, REMITT and REER are statistically significant in explaining economic growth evolution in the West Africa with the t-statistic value of $-0.912028,0.636562$ and 2.344571 for TOPEN, REMITT and REER respectively.

Furthermore, our estimates show that both remittance and trade openness are important sources of economic growth in the West Africa. To be more specific, the remittance variables have a positive and significant coefficient $(0.636562)$ which implies that $1 \%$ increase in trade openness leads to $63.66 \%$ increase in economic growth in the long run.

This result confirms that the trade openness contributes to the improvements of the economic growth that is in line with the recent empirical studies, for example, Nketiah et al., 2020 and Sarkar et al. (2018) which have a stance that trade openness led to economic growth. We can conclude so that, the trade openness implemented influences the level of development. This result lends support to Nketiah et al., (2020) who reported that trade openness is the main factor affecting economic growth in Ghana.

However, our results show that the impact of the remittance variable present also a positive coefficient $(0.636562)$ and significant $(0.0000)$, that can indicate its huge, but positive, relationship with the economic growth in the long-run in the West Africa. Investment also show a significant impact on economic growth.

This outcome confirms that the real effective exchange rate contributes to the enhancements of the economic growth which is in line with Adu-Gyamfi et al. (2020) determine the effects of Trade openness and inflation on the GDP growth for nine West-African Countries for the period from 1998 to 2017. This study employed pooled Ordinary Least Squares (OLS), Fixed Effects and Random effects test with panel data in arriving at the results. The study found that Real Exchange rate showed a positive significant impact on economic growth.

For more detail, a 5\% increase in the domestic savings will decrease the economic performance by $0.2953 \%$. This negative linkage ensures that where there is no development in the domestic savings it decreases the significant level of the GDP Growth.

\section{Conclusion and Recommendation}

\subsection{Conclusion}

The interest of this research paper was to examine the empirical link between remittances and economic growth using the most recent panel data (2004-2018) for some of the largest recipient countries of foreign remittances, namely; Burkina-Faso, Ghana, Guinea, Guinea-Bissau, Mali, Nigeria and Togo for the first time in the literature. The countries selection was based on data availability, in- 
cluding the most important economies and all the major sectors in the seven West African countries. Econometric modeling was performed using dynamic panel techniques: stationarity, cointegration, error correction model: Vector Error Correction Model (VECM) and Generalized Method of Moments (GMM). Our sample consists of 7 countries from Africa.

The evidence from the statistical analysis using the Generalized Method of Moments (GMM) model aggregated that real effective exchange rate, investment, remittance and trade openness have a positive and significant relationship on economic growth but only domestic savings which do not have a significant effect on economic growth.

The empirical evidence shows that remittance increases economic growth and is a major contributor to economic growth in short and long run. Overall, the empirical results show a strong implication in the West Africa, more precisely, the real effective exchange rate, remittance, investment and the trade openness have positive effects on the economic growth.

\subsection{Recommendations}

The following recommendations are based on the above findings and conclusions. Citizens of West Africa countries are encouraged and admonished not only to remit more funds to their countries but also transfer the acquired knowledge, skills and technologies back to their homeland. With this, industrialization will increase, and most problems will be fixed, including jobs for the packed unemployed youths.

Secondly, there is a need for prudence in the management of funds sent home by migrants. These monies and properties must be channeled into productive ventures and not for wastefulness. It must be a necessity and priority for the 7 West Africa countries to consider Macroeconomic stability and consistent productive policies, the security of life and property, political stability and also transparent rules and regulations. These among others will ensure economic growth.

Again, to earn the benefits of improved migrants' remittances under a globalized world economy, these seven (7) West Africa countries must create an investment climate that is alluring to foreign investors and Africans in the diaspora.

Lastly, there is equally the need for West Africa economies to rely more on domestic investment rather than on foreign capital inflows (Be it official or private inflows) for their economic growth.

\section{Limitations of the Study}

Similar to previous researches, our studies also face some difficulties throughout the whole process. Data constraint is one of the limitations of this paper. Moreover, this research only investigates in west Africa. The information and results discussed in this paper only describe the situation in West Africa and applicable in the case of only 7 West African countries. 
This paper is an attempt to investigate the cointegration and Granger causal relationship between remittances and economic growth in West Africa regarding Burkina-Faso, Ghana, Guinea, Guinea-Bissau, Mali, Nigeria, and Togo. Different from limited existing countries studies in West Africa, an advanced panel econometric methodology such as dynamic Panel data techniques considers the question of remittances on economic growth in West Africa.

\section{Future Research}

Based on our study, we encourage future researchers to solve several econometric problems before deciding which independent variable to include in the model. The purpose of doing so is to make sure the result is reliable and accurate in their studies. Besides, we are also using panel data in this paper. However, there are some disadvantages by using the panel data with only seven (7) West African countries. Therefore, whichever researchers who want to study this related topic are encouraged to occupy West Africa to avoid the econometric problem.

Moreover, future researchers are also encouraged to use different frequency sets of the econometric model as the GMM or Dynamic model to examine the consistency of the findings so that they can increase the reliability of the study. Future researchers are encouraged to study the relationship of the causal relationship variable with the GDP in other sectors as the financial field is a growing sector that may describe the GDP in West Africa. The result may be more significant when more sectors are to be considered.

\section{Funding}

This research received no external funding.

\section{Informed Content}

Not required.

\section{Acknowledgements}

We extend our special gratitude to the developers, managers and funding agencies of World Bank Development indicators (WDI) for granting access to these essential datasets in accordance to their specific data use and citation policies.

\section{Author Contributions}

Each author contributed equally to the research article. Data analysis was undertaken mainly by the first author. All authors have read and agreed to the published version of the manuscript.

\section{Conflicts of Interest}

The authors declare no conflicts of interest regarding the publication of this paper. 


\section{References}

Adams, R. H., Cuecueda, A., \& Page, J. (2013). The Impact of Remittances on Investment and Poverty in Ghana. World Development, 50, 24-40.

https://doi.org/10.1016/j.worlddev.2013.04.009

Adenutsi, E. D. (2011). Financial Development, International Remittances and Endogenous Growth in Ghana. Studies in Economics and Finance, 28, 68-89. https://doi.org/10.1108/10867371111110561

Adu-Gyamfi, G., Nketiah, E., Obuobi, B., \& Adjei, M. (2020). Trade Openness, Inflation and GDP Growth: Panel Data Evidence from Nine (9) West Africa Countries. Open Journal of Business and Management, 8, 314-328.

https://doi.org/10.4236/ojbm.2020.81019

Ang, A. (2007). Workers' Remittances and Economic Growth in the Philippines. Germany: Dynamics, Economic Growth and International Trade (DEGIT). Kiel: Institute for the World Economy.

Atiga, O., Nyeadi, J. D., \& Atogenzoya, C. A. (2014). The Impact of Exchange Rate Movement in Export: Empirical Evidence from Ghana. International Journal of Academic Research in Accounting, Finance and Management Sciences, 4, 41-48. https://doi.org/10.6007/IJARAFMS/v4-i3/980

Barajas, A., Chami, R., Connel, F., Gapen, M., \& Montiel, P. (2009). Do Workers' Remittances Promote Economic Growth? IMF Working Paper, WP/09/153, Washington DC: IMF. https://doi.org/10.5089/9781451873009.001

Bugamelli, M., \& Paterno, F. (2009). Do Workers' Remittances Reduce the Probability of Current Account Reversals? World Development, 37, 1821-1838. https://doi.org/10.1016/j.worlddev.2009.04.002

Catrinescu, N., Leon-Ledesma, M., Piracha, M., \& Quillin, B. (2009). Remittances, Institutions and Economic Growth. World Development, 37, 81-92. https://doi.org/10.1016/j.worlddev.2008.02.004

Chami, R., Fullenkamp, C., \& Jahjah, S. (2003). Are Immigrant Remittance Flows a Source of Capital for Development? IMF Working Paper WP/03/189.

Chowdhury, M. B. (2011). Remittances Flow and Financial Development in Bangladesh. Economic Modeling, 28, 2600-2608. https://doi.org/10.1016/j.econmod.2011.07.013

Combes, J., \& Ebeke, C. (2011). Remittances and Household Consumption Instability in Developing Countries. World Development, 39, 1076-1089.

https://doi.org/10.1016/j.worlddev.2010.10.006

Fayissa, B., \& Nsiah, C. (2010). Can Remittances Spur Economic Growth and Development? Evidence from Latin American Countries. Department of Economics and Finance Working Paper Series, Murfreesboro, TN: Middle Tennessee State University.

Gaiha, R., Imai, K. S., Ali, A., \& Kaicker, N. (2014). Remittances, Growth, and Poverty: New Evidence from Asian Countries. Journal of Policy Modeling, 36, 524-538.

Giuliano, P., \& Ruiz-Arranz, M. (2009). Remittances, Financial Development and Growth. Journal of Development Economics, 90, 144-152.

https://doi.org/10.1016/j.jdeveco.2008.10.005

Gupta, S., Patillo, C., \& Wagh, S. (2009). Effect of Remittances on Poverty and Financial Development in Sub-Saharan Africa. World Development, 37, 104-115.

https://doi.org/10.1016/j.worlddev.2008.05.007

Hasan, A. R. (2006). Harnessing Remittances for Economic Development of Bangladesh. INAFI Bangladesh Working Paper Series 1. 
Im, K. S., Pesaran, M. H., \& Shin, Y. (2003). Testing for Unit Roots in Heterogeneous Panels. Journal of Econometrics, 115, 53-74. https://doi.org/10.1016/S0304-4076(03)00092-7

Jalil, A., \& Feridun, M. (2011). The Impact of Growth, Energy and Financial Development on the Environment in China: A Cointegration Analysis. Energy Economics, 33, 284-291. https://doi.org/10.1016/j.eneco.2010.10.003

Javid, M., Umaima, A., \& Qayyum, A. (2012). Impact of Remittances on Economic Growth. Academic Research International, 2, 433-447.

Jones, C., \& Driffield, N. (2013). Impact of FDI, ODA and Migrant Remittances on Economic Growth in Developing Countries: A System Approach. European Journal of Development Studies, 25, 173-196. https://doi.org/10.1057/ejdr.2013.1

Jongwanich, J. (2007). Workers' Remittances, Economic Growth and Poverty in Developing Asia and the Pacific Countries. UNESCAP Working Paper, WP/07/01.

Kahouli, B., \& Maktouf, S. (2014). Trade Creation and Diversion Effects in the Mediterranean Area: Econometric Analysis by Gravity Model. The Journal of International Trade \& Economic Development: An International and Comparative Review, 24, 76-104. https://doi.org/10.1080/09638199.2013.873479

Kanu, S. I., \& Ozurumba, B. A. (2013). Migrant's Remittances and Economic Growth in Sub Saharan Africa: Evidence from Nigeria, Ghana, and South Africa. Interdisciplinary Journal of Contemporary Research in Business, 4, 534-550.

Khawaja, A., \& Nath, H. (2010). Worker's Migration and Remittances in Bangladesh. Journal of Business Strategies, 27, 29-52.

Lartey, K. K. E. (2011). Remittances, Investment, and Growth in Sub-Saharan Africa. The Journal of International Trade and Economic Development: An International and Comparative Review, 22, 1038-1058. https://doi.org/10.1080/09638199.2011.632692

Levin, A., Lin, C.-F., \& Chu, C.-S. J. (2002). Unit Root Tests in Panel Data: Asymptotic and Finite-Sample Properties. Journal of Econometrics, 108, 1-24. https://doi.org/10.1016/S0304-4076(01)00098-7

Maddala, G. S., \& Wu, S. (1999). A Comparative Study of Unit Roots Tests with Panel Data and a New Simple Test. Oxford Bulleting of Economics and Statistics, No. 61, 631-652. https://doi.org/10.1111/1468-0084.61.s1.13

Majumder, S. C., \& Donghui, Z. (2016). Relationship between Remittance and Economic Growth in Bangladesh: An Autoregressive Distributed Lag Model (ARDL). European Researcher, Series A, 104, 156-167. https://doi.org/10.13187/er.2016.104.156

Marwan, N. F., Kadir, A. A. N., Hussin, A., Zaini, A. A., Rashid, A. E. M., \& Helmi, G. A. Z. (2013). Export, Aid, Remittance and Growth: Evidence from Sudan. Procedia Economics and Finance, 7, 3-10.

Mcgillivray, M., Iamsiraroj, S., \& Feeny, S. (2014). Remittances and Economic Growth. Larger Impact in Smaller Countries?

McKinnon, R. (1973). Money and Capital in Economic Development. Washington DC: Brookings Institution.

Molina, L. Lopez, H., \& Bussolo, M. (2007). Remittances and the Real Exchange Rate. World Bank Policy Research Working Paper 4213, Washington, DC: World Bank.

Moradbeigi, M., \& Law, S. H. (2017). The Role of Financial Development in the Oil-Growth Nexus. Resources Policy, 53, 164-172.

https://doi.org/10.1016/j.resourpol.2017.06.016

Naiditch, C., \& Vranceanu, R. (2010). Equilibrium Migration with Invested Remittances: The EECA Evidence. European Journal of Political Economy, 26, 454-474. 
https://doi.org/10.1016/j.ejpoleco.2010.05.003

Nketiah, E., Adjei, M., Boamah, B. B., \& Adu-Gyamfi, G. (2019). The Impact of Remittance on the Real Exchange Rate in Ghana. Open Journal of Business and Management, 7, 1862-1879. https://doi.org/10.4236/ojbm.2019.74128

Paul, B., Uddin, G. S., \& Noman, A. (2011). Remittances and Output in Bangladesh: An ARDL Bounds Testing Approach to Cointegration. International Review of Economics, 58, 229-242. https://doi.org/10.1007/s12232-011-0120-2

Pradhan, G., Upadhaya, M., \& Upadhaya, K. (2008). Remittances and Economic Growth in Developing Countries. European Journal of Development Research, 20, 497-506. https://doi.org/10.1080/09578810802246285

Ramirez, D. M. (2013). Do Financial and Institutional Variables Enhance the Impact of Remittances on Economic Growth in Latin America and the Caribbean? A Panel Cointegration Analysis. International Atlantic Economic Society, 19, 273-288. https://doi.org/10.1007/s11294-013-9407-2

Rao, B. B., \& Hassan, G. (2011). A Panel Data Analysis of the Growth Effects of Remittances. Economic Modeling, 28, 701-709. https://doi.org/10.1016/j.econmod.2010.05.011

Salahuddin, M., \& Gow, J. (2015). The Relationship between Economic Growth and Remittances in the Presence of Cross-Sectional Dependence. The Journal of Development Areas, 49, 207-221. https://doi.org/10.1353/jda.2015.0007

Sarkar, M., Rahman, M., Islam, M., Sikdar, M., \& Khan, A. (2018). Relationship between Remittance and Economic Growth: Evidence from Bangladesh. American Journal of Trade and Policy, 5, 15-20. https://doi.org/10.18034/ajtp.v5i3.440

Selvanathan, S., Siddique, A., \& Selvanathan, E. A. (2012). Remittances and Economic Growth: Empirical Evidence from Bangladesh, India and Sri Lanka. Journal of Development Studies, 45, 1045-1062. https://doi.org/10.1080/00220388.2012.663904

Vargas, S. C., Jha, S., \& Sujiarto, G. (2009). Remittances in Asia: Implications for the Fight against Poverty and the Pursuit of Economic Growth. ADB Economic Working Paper Series No. 182, Manila: Asian Development Bank.

Ziesemer, T. H. W. (2010). The Impact of the Credit Crisis on Poor Developing Countries: Growth, Worker Remittances, Accumulation and Migration. Economic Modeling, 27, 1230-1245. https://doi.org/10.1016/j.econmod.2010.02.008

Ziesemer, T. H. W. (2012). Worker Remittances, Migration, Accumulation, and Growth in Poor Developing Countries: Survey and Analysis of Direct-Indirect Effects. Economic Modeling, 29, 103-118. https://doi.org/10.1016/j.econmod.2011.08.013 


\section{Abbreviations}

\begin{tabular}{cc} 
GDPGROWTH & Gross Domestic Product Growth \\
REMITT & Remittance \\
REER & Real Effective Exchange Rate \\
TOPEN & Trade Openness \\
INVESTMENT & Investment \\
DOMESTICSAVINGS & Domestic Savings \\
WDI & World Development Indicators \\
WGI & World Governance Indicators \\
\hline
\end{tabular}

